\title{
La alegoría de la República en la Guerra Civil Española
}

\author{
Estíbaliz PÉREZ ASPERILLA \\ Universidad Complutense de Madrid \\ estibaliz_asper@hotmail.com
}

Recibido: 24 de junio de 2014

Aceptado: 23 de octubre de 2014

\begin{abstract}
Resumen
A través del método iconológico de Erwin Panofsky se puede comprobar cómo la alegoría de la República Española no sólo adoptó sus vestimentas, atributos y demás rasgos característicos de acuerdo al bando que representaba, sino que muchos de estos elementos le fueron heredados a través diferentes diosas que debido a la imposición de las religiones monoteístas fueron cayendo en el olvido. Deidades como Deméter, Hispania, Cibeles, Atenea o Maat volvían a estar presentes en la sociedad gracias a esta nueva Diosa Republicana que consiguió llenar de esperanza los corazones de sus seguidores.
\end{abstract}

Palabras clave: Cartel; Guerra Civil Española; República; alegoría; diosa.

\section{Republic allegory in the Spanish Civil War}

\begin{abstract}
Through the iconology method by Erwin Panofsky, it can be proved how the Spanish Republic allegory not only adopted her clothes, attributes and other characteristic features according to the side she represented, but many of these elements were inherited through different goddesses who due to the imposition of the monotheistic religions were being forgotten. Deities such as Demeter, Hispania, Cibeles, Atenea or Maat came back in society thanks to this new Republican Goddess who managed to fill with hope her believers' hearts.
\end{abstract}

Key words: Poster; Spanish Civil War; Republic; allegory; goddess.

\section{Referencia normalizada:}

Pérez Asperilla, E. (2014). La alegoría de la República en la Guerra Civil Española. Historia y Comunicación Social. Vol. 19. Páginas 99-111.

Sumario: 1. Introducción. 2. Metodología. 2.1. Método iconológico de Erwin Panofsky. 2.2. El cosmos de cultura y la estructura espacio-temporal. 3. Las tres caras de la Diosa Republicana. 3.1. La Diosa entre las tropas. 3.2. Portadora de la Justicia. 3.3. La Gran Madre Republicana. 4. Conclusiones. 5. Referencias bibliográficas. 


\section{Introducción}

Los carteles realizados durante la Guerra Civil Española, además de ser considerados como obras de arte, son auténticos materiales históricos. A través de la imagen no sólo narran cómo se desarrolló el conflicto bélico, sino el ambiente que se vivía en cada uno de los bandos, la situación que el ciudadano de a pie estaba viviendo, así como el rol de la mujer relacionado sobre todo con la maternidad, el cuidado y el apoyo a los soldados en combate.

Sin embargo, había una mujer cuya fuerza y energía resaltaba frente a las demás. Se trataba de un personaje femenino que aparecía como uno de los principales protagonistas en numerosos carteles representando no sólo a una mujer maternal asociada con el cuidado, sino como un personaje femenino fuerte y luchador que emergía como un pilar fundamental durante el desarrollo de la guerra.

Personificada como una auténtica deidad, la alegoría de la República inundaba muchos de los carteles que ilustraban la Guerra Civil Española. A pesar de tratarse de una mera imagen dibujada en papel, el bando republicano la llenaba de vida convirtiéndola en madre, guerrera, guía, apoyo e inyección de fuerza y esperanza.

\section{Metodología}

\subsection{Método iconológico de Erwin Panofsky}

En cuanto a la metodología se refiere, se ha optado por la aplicación del método iconológico de Erwin Panofsky ${ }^{1}$, el cual tiene como origen los planteamientos metodológicos de Aby Warburg, además de la introducción complementaria de otros métodos y técnicas de diferentes estudiosos como Didi-Huberman.

El método iconológico de Erwin Panofsky se compone de tres niveles. El primero corresponde al nivel pre-iconográfico que consiste en una descripción detallada de la imagen identificando formas, colores, líneas, perspectivas, número de figuras, vestimenta, luces, decorado, gestos, etc.-. El segundo nivel sería el iconográfico donde se lleva a cabo una clasificación de las imágenes atendiendo al espacio y al tiempo sin realizar ningún tipo de interpretación y donde se necesita tener conocimiento de fuentes literarias y una familiaridad con temas y conceptos específicos. Y por último, nos encontraríamos con el nivel iconológico en el que se realiza una interpretación final teniendo en cuenta al artista, el contexto histórico y cultural, la intencionalidad, la función y el significado.

\subsection{El cosmos de cultura y la estructura espacio-temporal}

Erwin Panofsky hacía referencia a cómo el humanista fechaba y localizaba el material primario del que disponía para poder así obtener un cosmos de cultura al 
que consideraba como una estructura espacio-temporal donde todos los elementos se observaban, se relacionaban con otros materiales, se organizaban y/o clasificaban y se interpretaban o descifraban ${ }^{2}$. En cuanto al tiempo se refiere, aludía sobre todo al pasado, considerando el presente como algo deformante.

"Nos interesa el pasado porque, en último término, nada hay menos real que el presente. Para captar la realidad hay que apartarse del deformante presente y sin coaccionadoras urgencias. Las ciencias puras aprehenden y formulan las leyes que presiden un cambio natural observado por el hombre de ciencia; las humanidades no se ocupan de lo que pasa, sino que tratan de revivir lo que parece muerto: el pasado." (Panofsky, 1994: XXIII)

Pero desde mi punto de vista, es necesario tener muy en cuenta el presente y las diferentes interpretaciones que se pueden dar según la época en la que nos encontremos. Por ello, mis ideas respecto a la variable tiempo difieren ligeramente de las de Panofsky, acercándose más a otros estudiosos como George Didi-Huberman quien entendía la imagen como anacrónica siendo ésta "“atemporal", "absoluta", "eterna"» (Didi-Huberman, 2005: 28, 29).

Dicho esto, para poder realizar una buena interpretación del material seleccionado, era necesario llevar a cabo nuestro propio cosmos de cultura. Para ello, se clasificaron aquellos carteles pertenecientes al periodo de la Guerra Civil Española (desde 17 de julio de 1936 al 1 de abril de 1939), así como aquellas ilustraciones pertenecientes a la República y a la postguerra donde también se representaba la alegoría de la República Española y que podían complementar el estudio en cuestión ${ }^{3}$.

En cuanto al tiempo se refiere, se consideró la fecha en la que se encuadraba el material analizado y por lo que al espacio respecta, se atendió al lugar donde se realizó la obra en concreto además de la autoría de la misma.

Este cosmos de cultura se asemeja a lo que Aby Warburg presentó como Atlas Mnemosyne, cuya finalidad era la de explicar a través del texto y la imagen, el proceso histórico de la creación artística en la Edad Moderna buscando sus fundamentos en la Antigüedad ${ }^{4}$. Los textos literarios se cotejaban de forma conjunta con las obras de arte permitiendo de esta forma aproximarse a lo que la sociedad de esa época en concreto sentía respecto a las obras de arte que se habían realizado en aquel contexto.

"Un recurso muy novedoso en el ámbito de la historia del arte fue el de la consulta de textos literarios cotejándolos conjuntamente con las obras de arte, tratando con ello de aproximarse a lo que sentían los hombres en cuyo entorno se produjeron las obras artísticas que eran objeto de su estudio. En una continua confrontación entre imagen y texto, Warburg ponía de relieve el valor expresivo de las formas y de la estructura semántica de las obras.” (Gombrich, 1992: 94) 


\section{Las tres caras de la Diosa Republicana}

\subsection{La diosa entre las tropas}

Uno de los papeles cruciales de esta nueva Diosa era el de protectora de la España Republicana acompañando a los soldados en combate (fig. 1), guiándolos en todo momento e incluso formando parte de ellos y siendo un nexo de unión indispensable entre cada uno de sus componentes apostando por la unidad de las tropas como requisito indispensable para ganar la batalla (fig. 2).

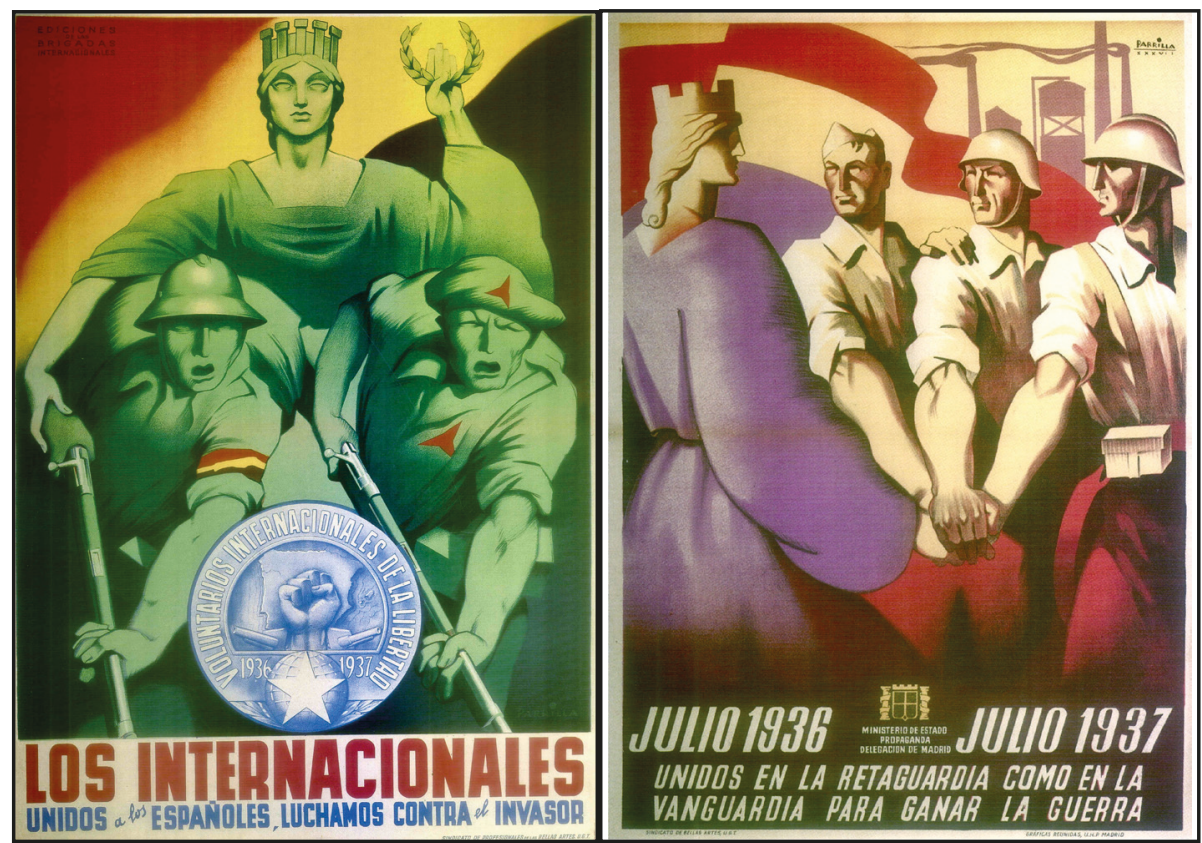

Fig. 1. Parrilla, 1937. 100 x 72. Cromo. Madrid Sindicato de Profesionales de las Bellas Artes

Fig. 2. Parrilla, 1937 (99 x 70). Madrid. Gráficas Reunidas

La protección de los soldados en el combate y su carácter combatiente recuerdan a diosas como Atenea -deidad protectora de Atenas- sobre todo si se tiene en cuenta su epíteto ritual de Palas Atenea, ya que fue un nombre que le fue dado al derrotar a un gigante en la guerra contra los titanes apoderándose seguidamente de sus poderes ${ }^{5}$.

“Además, él mismo [Zeus] hizo nacer de su cabeza a Atenea, de verdes ojos, terrible, belicosa, jefe de expediciones, insaciable, venerable, a la que agrandan los gritos, las guerras y las luchas." (Hesiodo, 1986: 54)

En la Ilíada de Homero se puede comprobar cómo se le asocia no sólo con los conflictos armados, sino que era considerada como gran imperante en las batallas: 
"[...] Atenea descendió presurosa del Olimpo, cual nocturna mensajera, para que tomáramos las armas [...].” (Homero, 1967: 219)
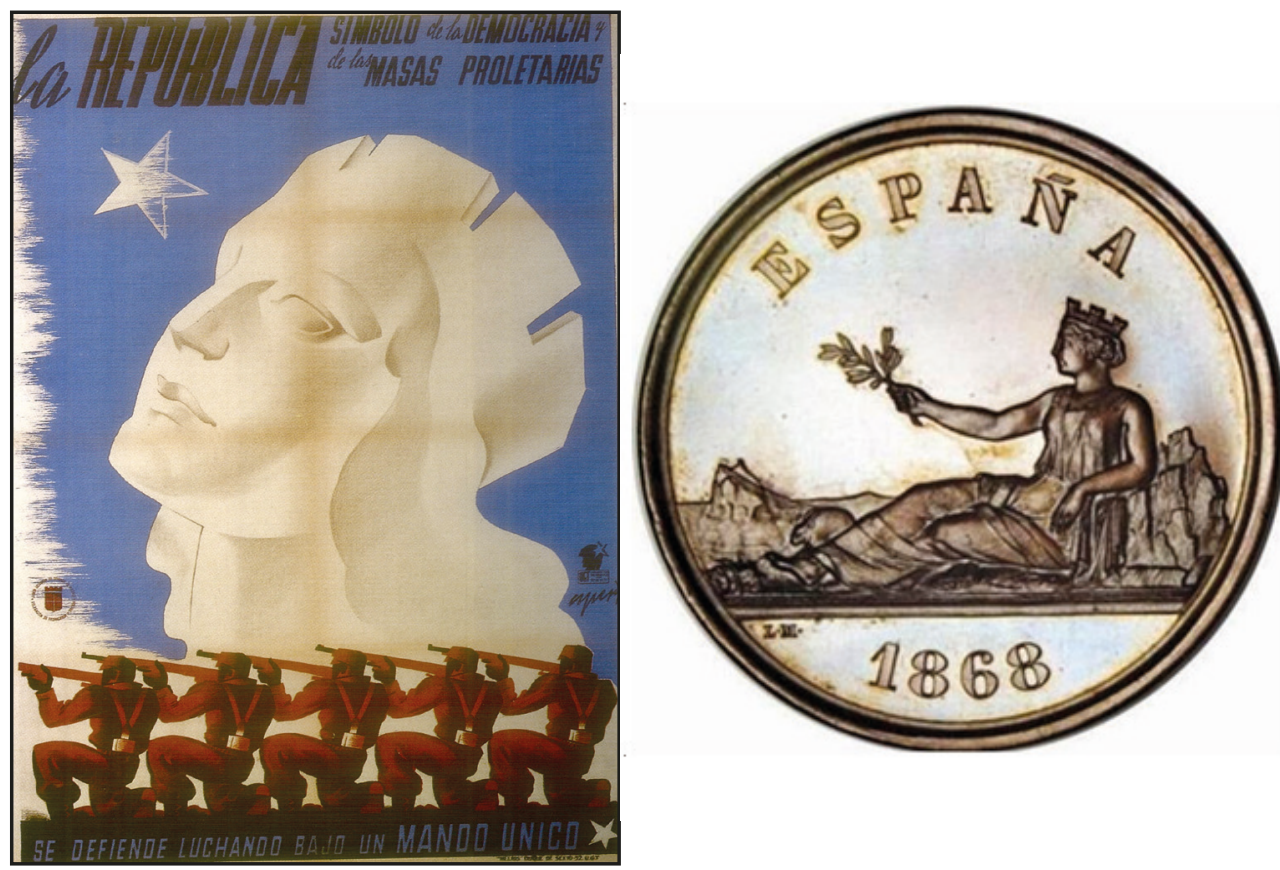

Fig. 3. Espert, 1937 (100 x 71) Madrid. Sindicato de Profesionales de las Bellas Artes Fig. 4. Moneda española de 1868

No obstante, a pesar de estar relacionada con la protección no sólo de Atenas, sino de los combatientes, esta diosa no se presentaba como una guerrera sangrienta que acababa con las vidas de decenas de guerreros del bando opuesto, sino que -tal como sucede con la Diosa Republicana- se preocupaba por respaldar y guiar a sus soldados sirviendo como gran pilar apoyo (fig. 3).

Acompañada en muchas de sus representaciones de la corona de laurel ${ }^{6}$ (fig. 1), era símbolo a su vez de victoria ligada en todo momento con la España Republicana. Si Atenea era considerada como la gran protectora de Atenas, esta nueva Diosa ilustrada en los carteles de la Guerra Civil Española era fiel defensora de su país, tal como se puede apreciar en la corona mural que porta sobre su cabeza -símbolo del país al que protegía-. Dicha corona ya se incluía en las monedas de la segunda mitad del siglo XIX donde se introducía como gran protagonista a esa Hispania coronada y acompañada del laurel como uno de sus principales atributos (fig. 4). 


\subsection{Portadora de Justicia}

La victoria representada a través de las hojas de laurel no sólo iba ligada a la batalla (fig. 1), sino también al voto (fig. 5) siendo también acompañada de la justicia mediante otros dos atributos propios de esta Diosa Republicana -la balanza y la espada (figs. 5 y 6 )-.

"La balanza es conocida como símbolo de la justicia, de la mesura, de la prudencia y del equilibrio, porque su función corresponde precisamente a la ponderación de los actos. Asociada con la espada, la balanza sigue siendo la Justicia, pero doblada por la Verdad. En el plano social son éstos los emblemas de las funciones administrativa y militar [...]." (Chevalier; Gheerbrant, 2007: 169)

Si se visualizan las representaciones de diosas como la griega Temis -personificación de la Ley ${ }^{7}$-, ambos elementos también eran propios de este tipo de divinidades relacionadas con la justicia y la verdad. Si se comparan las figuras 5 y 6 con la 7 -donde aparece fotografiada una estatua de Temis-, las representaciones son muy parecidas a excepción de la banda que tapa los ojos de la diosa griega y la corona mural característica de la Diosa Republicana, ya que incluso la vestimenta de ambas guarda también estrechas similitudes.

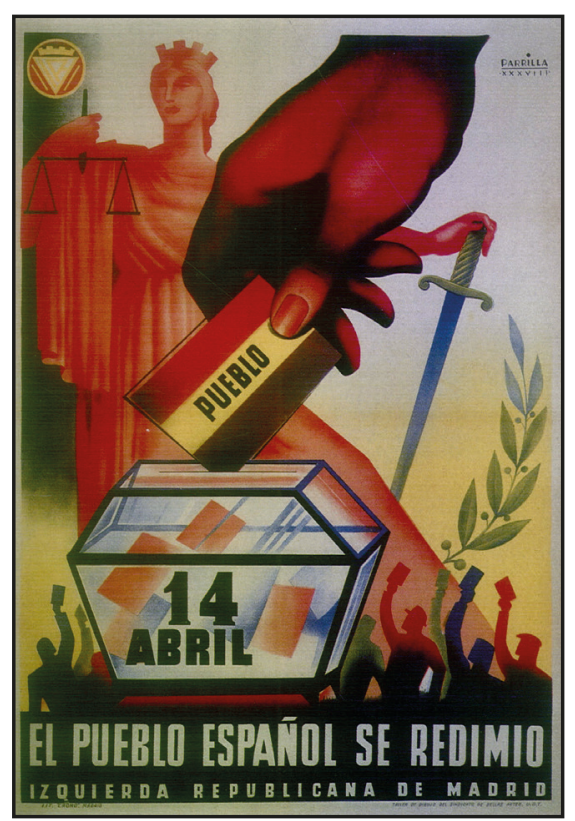

Fig. 5. Parrilla, 1938 (101 x 70). Madrid 


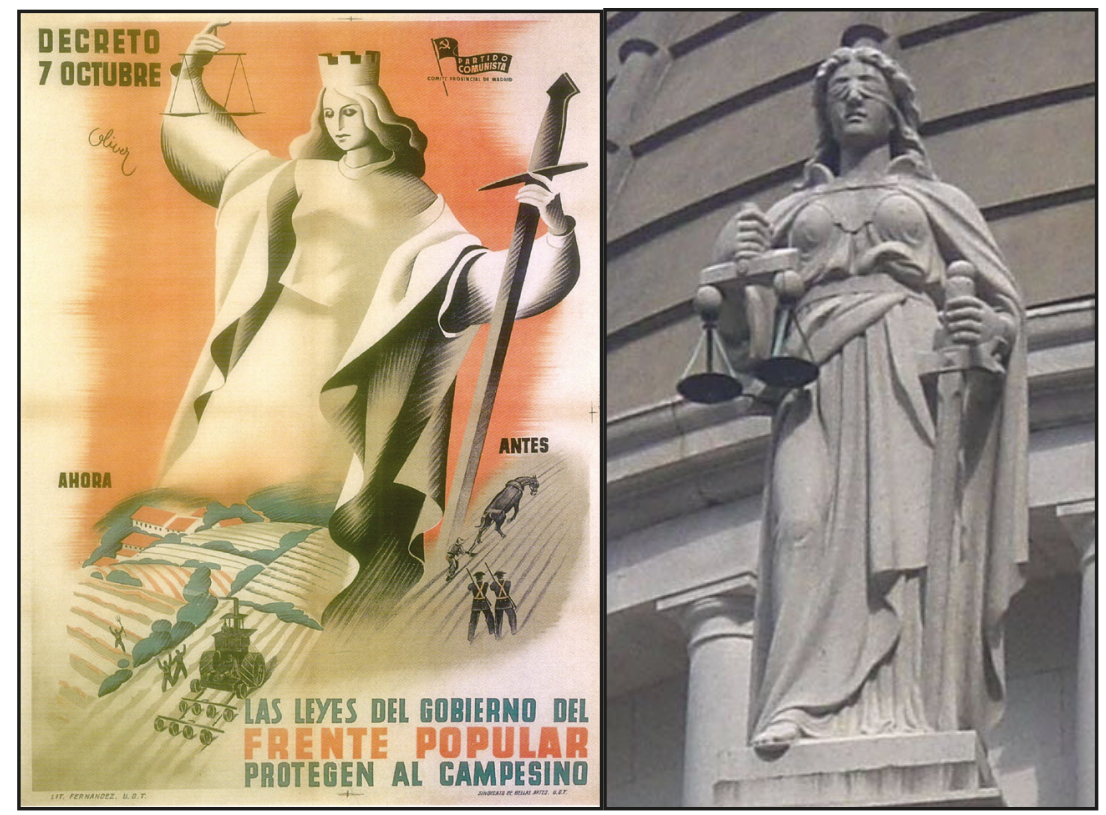

Fig. 6. Oliver, 1937 (99 x 71) Madrid

Fig. 7. Temis armada con una espada y una balanza. Legislative Council Building, Hong Kong

Si nos remontamos a la mitología egipcia, estas deidades femeninas encargadas de la justicia y la defensa de la verdad también aparecen personificadas a través de diosas como Maat quien a pesar de no portar la espada y la balanza como atributos característicos, era considerada como una fuerte defensora de la justicia haciendo uso de su pluma para obtener el veredicto final (fig. 8):

"La pluma de Maat se colocaba en la balanza de la justicia para comparar su peso con el del corazón del que había muerto. Si el corazón era más pesado que la pluma, la balanza se inclinaba y el corazón caía a las fauces abiertas de Ta Urt, el monstruo con cabeza de cocodrilo, cuerpo de hipopótamo y pies de león que estaba agazapado debajo." (Baring; Cashford, 2005: 308)

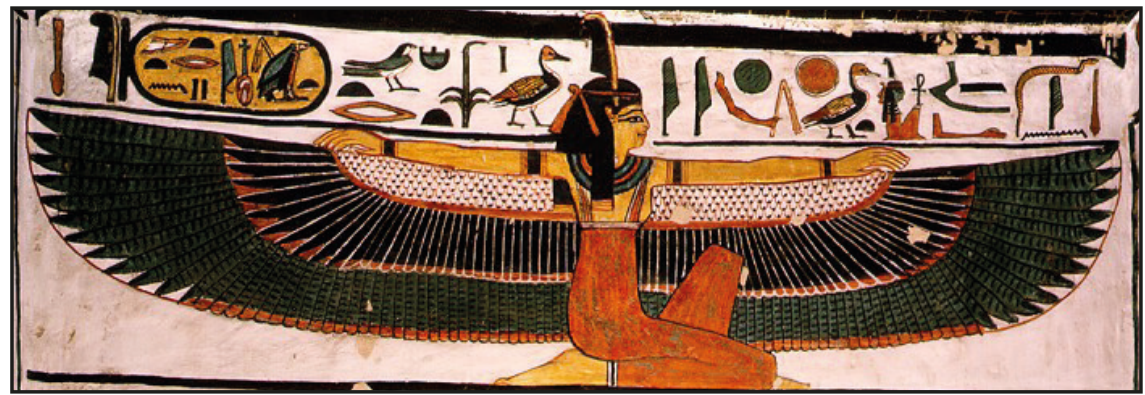

Fig. 8. La diosa Maat en el dintel que enmarca la entrada de la tumba de Nefertari, esposa de Ramsés II (XIX dinastía, c. 1290-1224 a. C.) 
Las alas características de diosas como Maat, Isis u otras deidades celtas como Morrigan o Badb8 son leves retazos que siguen persistiendo de las grandes Diosas Pájaro de la Prehistoria que fueron derrocadas por la imposición de las religiones monoteístas con los dioses masculinos como únicos protagonistas9. Retazos que vuelven a estar presentes en algunas de las imágenes de la Diosa Republicana tal y como sucede en la figura 9 donde además de estar de nuevo ligada con la justicia y la Ley -léase el texto que acompaña a la ilustración- representa una tercera faceta relacionada con la maternidad y la alimentación (ver apartado 3.3.).

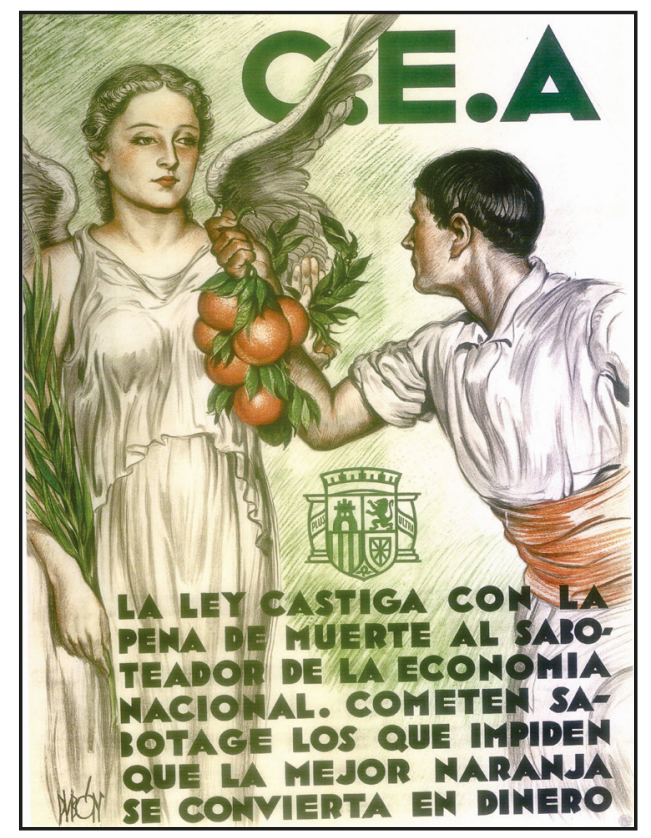

Fig. 9. Dubon, 1938 (100 x 70). Dura. Valencia. CEA

\subsection{La gran madre republicana}

Además de guardar ciertas semejanzas con personajes femeninos como Maat en cuanto a su representación como mujer alada se refiere, otras divinidades como Deméter o Cibeles también viven en el corazón de esta diosa que no sólo protege al soldado, sino al campesino, a las madres, a los niños y a todo el ciudadano de a pie velando por su bienestar (fig. 10). Y es que estas diosas madre también se relacionan con la justicia y la verdad compartiendo características y elementos en común tal como sucede con Cibeles y Deméter:

"La justicia es parte de la imagen de Cibeles, como ocurre con Inanna en Sumer y Maat en Egipto; los archivos legales de Atenas se almacenaban en su templo. Como a Inanna, Isis y Deméter, se la consideraba la fundadora de la agricultura y la ley. El 
emperador Juliano en el siglo IV d. C. narró la historia de cómo el templo de Cibeles se estableció en primer lugar en Atenas [...]." (Baring; Cashford, 2005: 448, 449)

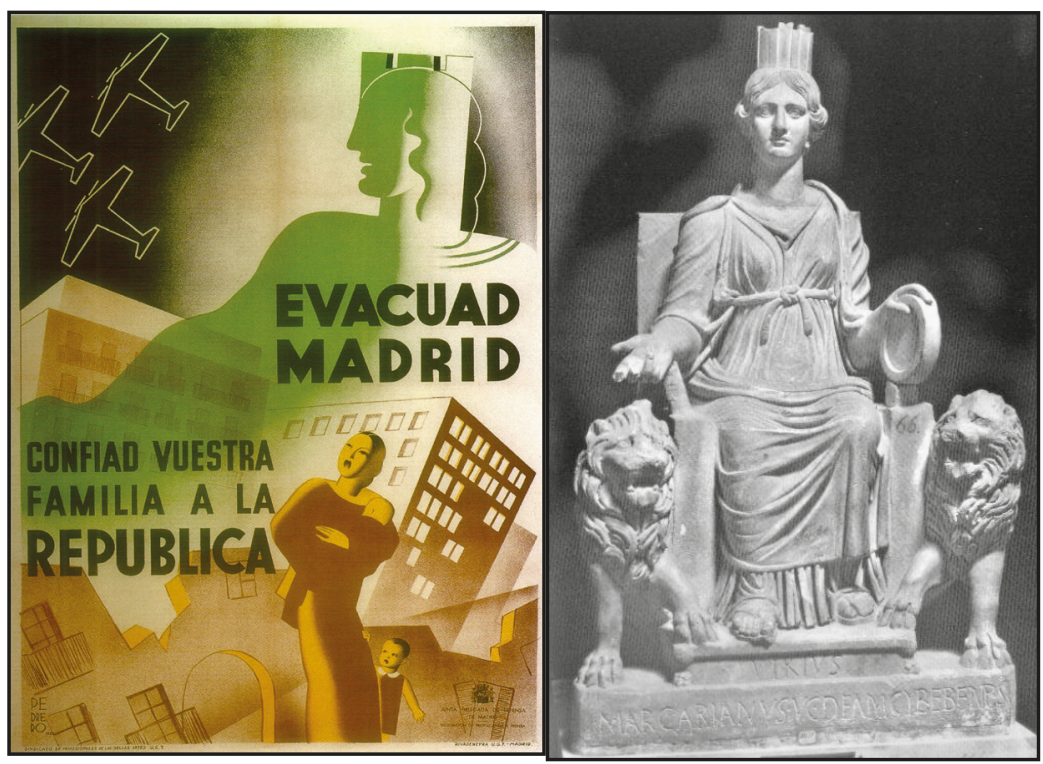

Fig. 10. Pedrero, 1937 (100 x 70) Madrid. Sindicato de Profesionales de las Bellas Artes

Fig. 11. Cibeles entronizada con sus leones (pieza romana del siglo II o III d. C.)

Pero Cibeles no sólo comparte elementos relacionados con la justicia, sino que además de su carácter maternal, en ella se vuelve a percibir la protección de su país a través de la corona mural que porta sobre su cabeza (fig. 11) y que ya se ha podido contemplar en varias de las representaciones de la Diosa Republicana y de otros personajes femeninos como la Hispania en el siglo XIX (fig. 4).

Así, igual que el mito de Deméter y su hija Perséfone narra la infertilidad de la tierra al bajar esta última al inframundo ${ }^{10}$, la Diosa Republicana es símbolo de fertilidad y buenas cosechas transmitiendo la falta de productividad en la agricultura si ella desaparece. Además de las hojas de laurel, en muchas de sus ilustraciones porta entre sus manos la espiga de trigo, símbolo de abundancia (fig. 9).

"El trigo cortado es como el árbol cortado en Creta y Roma, la imagen de lo que muere cada día y, sin embargo, revive. Como Osiris, Atis y Adonis, y como Perséfone, la hija, la siega del trigo no significaba la muerte de lo que hacía crecer al trigo; de hecho, la paradoja del trigo cortado es que es su muerte la que trae de vuelta la vida." (Baring; Cashford, 2005: 443) 


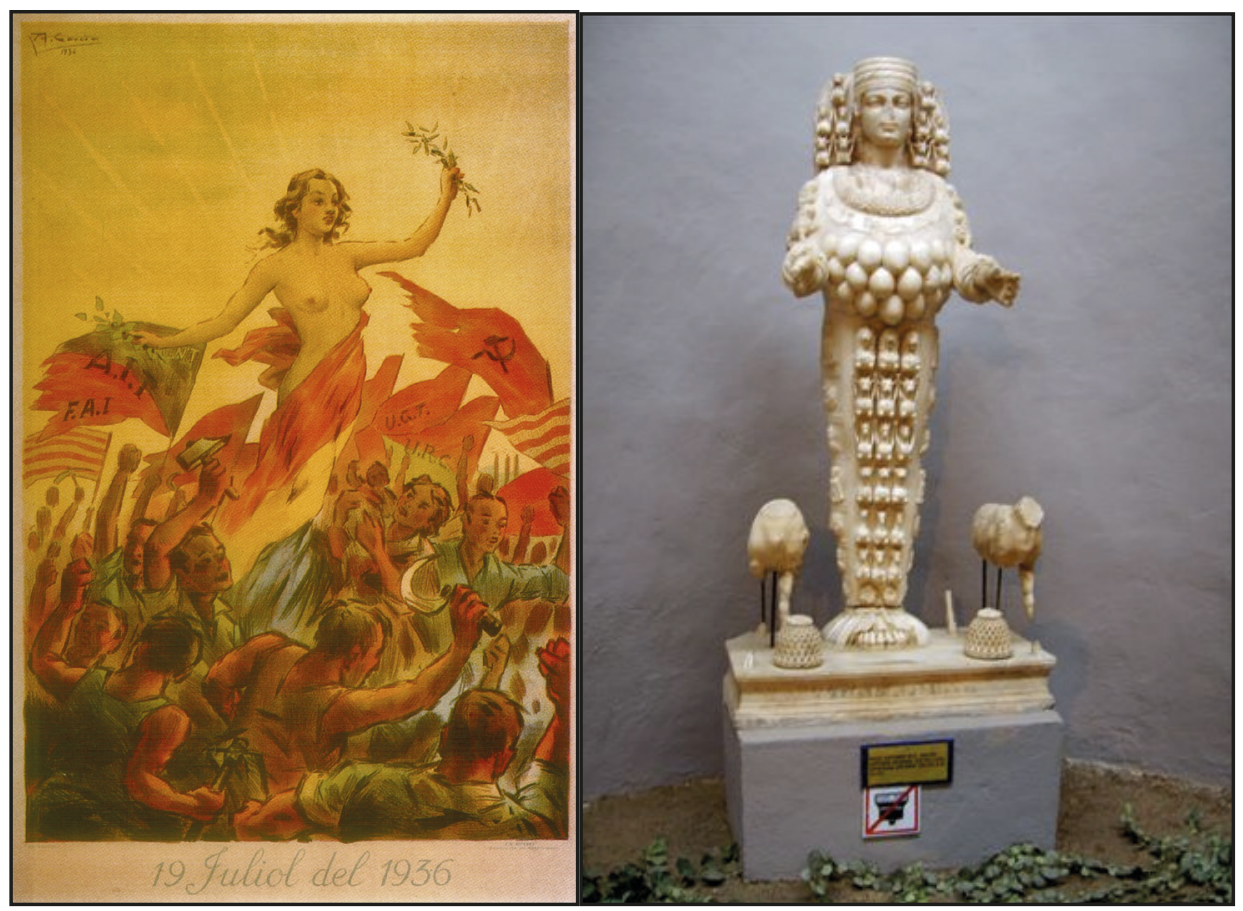

Fig. 12. García, 1936 (64 x 41). Barcelona

Fig. 13. La Artemisa de Éfeso, siglo I d. C. Museo Arqueológico de Éfeso

Por último, en la figura 12 se puede observar también la influencia de Artemisa al aparecer con su torso desnudo tal como sucede con esta última deidad en muchas de sus representaciones presentándose como una mujer con numerosos pechos al descubierto y mostrando así su carácter nutricio (fig. 13). El resplandor que desprende la Diosa Republicana en este cartel confirma su consideración como divinidad entre sus seguidores apareciendo incluso levitando y en un tamaño mayor que el resto de los personajes incluidos en la ilustración. De esta forma, la alegoría se convierte en una auténtica Diosa que no sólo protege a sus fieles seguidores, sino que consigue una unión entre éstos inundando al bando republicano de esperanza y tesón.

\section{Conclusiones}

La alegoría de la República en la Guerra Civil Española es un buen ejemplo de cómo diferentes diosas que han ido cayendo en el olvido vuelven a abrirse paso ante una sociedad patriarcal mediante el poder de la imagen. Pero no sólo se observan leves semejanzas o características comunes de alguna deidad en concreto, sino que la Diosa Republicana se conforma gracias a la herencia de numerosas diosas de diferen- 
tes mitologías que consiguen como resultado su reaparición mediante un personaje femenino que se creó como alegoría y que pasó a latir con fuerza entre sus seguidores de tal manera que aún sigue resonando entre aquellos que todavía apuestan por ella.

A pesar de no rendir culto a las numerosas divinidades femeninas, éstas siguen presentes en nuestro día a día gracias a la constante reinvención de los medios ofreciendo nuevas lecturas y adaptándose a lo que la sociedad demanda en cada época. Así, frente a las múltiples representaciones de la mujer como esposa fiel, madre ejemplar y ama de casa ideal, la imagen de personajes femeninos representados y/o construidos mediante rasgos y elementos propios de divinidades que destacan por cualidades asociadas a la fuerza, la justicia y la protección entre otras cuestiones, consigue una revalorización del género femenino lejana a los estereotipos y las normas establecidas por la sociedad. De esta forma, se sigue presentando a la mujer como madre y apoyo, pero llena de fuerza e incluso con un papel activo en los conflictos bélicos sin quedar relegada a un segundo plano tal como muestran muchos de los carteles de guerra no sólo a nivel nacional, sino mundial.

\section{Referencias bibliográficas}

BARING, ANNE; CASHFORD, JULES (2005). El mito de la Diosa. Madrid: Ediciones Siruela.

BIBLIOTECA NACIONAL (1990). Catálogo de carteles de la República y la Guerra Civil Españolas. Madrid: Dirección General del Libro y Bibliotecas.

CARULLA, JORDI; CARULLA, ARNAU (1997). La Guerra Civil en 2000 Cartells. República-Guerra Civil-Postguerra. Barcelona: Postermil. (Volumen I).

CARULLA, JORDI; CARULLA, ARNAU (1997). La Guerra Civil en 2000 Cartells. República-Guerra Civil-Postguerra. Barcelona: Postermil. (Volumen II).

DESPROCHES NOBLECOURT, CHRISTIANE (1999). La mujer en tiempos de los faraones. Madrid: Editorial Complutense.

DIDI HUBERMAN (2005). Ante el tiempo. Buenos Aires: Adriana Hidalgo editora. CHEVALIER, JEAN; GHEERBRANT, ALAIN (2007). Diccionario de los símbolos. Barcelona: Herder editorial.

GIL PECHARROMÁN, JULIO (2002).- Historia de la Segunda República Española (1931-1936). Madrid: Biblioteca Nueva.

GOMBRICH, E. H. (1992). Aby Warburg. Una biografía intelectual. Madrid: Alianza Editorial.

GOÑI ZUBIERTA, CARLOS (2005). Alma Femenina. La mujer en la mitología. Madrid: Editorial Espasa Calpe.

GRAHAM, HELEN (2006). La República Española en guerra (1936-1939). Barcelona: Debate.

HESIODO (1986). Teogonía, Trabajos y días, Escudo, Certamen. Madrid: Alianza Editorial.

HOMERO (1967). La Ilíada. Barcelona: Editorial Bruguera. 2a edición. 
MARKALE, JEAN (2005). La mujer celta. Mito y sociología. Barcelona: MRA ediciones.

PANOFSKY, ERWIN (1979). El significado en las artes visuales. Madrid: Alianza editorial.

PANOFSKY, ERWIN (1994). Estudios sobre iconología. Madrid: Alianza Editorial. PÉREZ ASPERILLA, ESTÍBALIZ (2013). Björk: la revolución de la diosa. Madrid: Universidad Complutense de Madrid.

RODRÍGUEZ, PEPE (1999). Dios nació mujer. Barcelona: Ediciones B.

SCOTT LITTLETON, C. (2004). Mitología. Antología ilustrada de mitos y leyendas del mundo. Barcelona: Editorial Blume.

SHLAIN, LEONARD (2000). El alfabeto contra la diosa. El conflicto entre la palabra y la imagen, el poder masculino y el poder femenino. Madrid: Editorial Debate.

WARBURG, ABY (2010). Atlas Mnemosyne. Madrid: Ediciones Akal.

\section{Notas}

1. Panofsky, 1994: 45-58

2. Panofsky, 1979: 21-25

3. Los carteles presentes en este artículo son sólo una muestra del cosmos de cultura creado para este estudio compuesto por 53 imágenes (carteles, postales y portadas de revista).

4. Fernando Checa en Warburg, 2010: 138

5. Scott Littleton, 2004: 177

6. "Arbusto consagrado a Apolo, simboliza la inmortalidad adquirida por la victoria. Por esto su follaje sirve para coronar a los héroes, a los genios y a los sabios. Árbol apolíneo, significa también las condiciones espirituales de la victoria, la sabiduría unida al heroismo." (Chevalier; Gheerbrant, 2007: 630)

7. "Para los griegos la balanza es un símbolo de la ley general de justicia, de orden, de equilibrio, de mesura, representado por Temis, que rige los mundos según una ley universal." (Chevalier; Gheerbrant, 2007: 170)

8. Pérez Asperilla, 2013: 116, 117

9. "La Diosa Pájaro era la encargada de proveer la humedad vital que precisaba el conjunto de la vida para seguir existiendo, y como ave acuática, representaba el nexo de unión entre la tierra y el cielo [...]. Sus elementos característicos, máscara o rostro con pico de ave, pechos, brazos en forma de alas y grabaciones con simbolismo acuático y pubiano, la muestran como fuente divina del alimento vital -leche y lluvia- o como donante de vida en general, eso es como la Diosa Donante de Vida." (Rodríguez, 1999: 217, 218)

10. Pérez Asperilla, 2013: 273 


\section{La autora}

Estíbaliz Pérez Asperilla es Diplomada en Turismo y Licenciada en Publicidad y Relaciones Públicas por la Universidad Complutense de Madrid. Especialista Agente para la Detección e Intervención Integral en Violencia de Género (Universidad Complutense de Madrid). Doctora en Ciencias de la Información. Especialidad en Técnicas y Procesos en la Creación de Imágenes: Aplicaciones sociales y estéticas. Departamento de Comunicación y Publicidad II. Facultad Ciencias de la Información. Universidad Complutense de Madrid. Investigadora en el Grupo de Investigación Arte, Arquitectura y Comunicación en la Ciudad Contemporánea. Campus de Excelencia Internacional Moncloa. Cluster Patrimonio. Universidad Complutense de Madrid. 